Check for updates

Cite this: RSC Adv., 2017, 7, 45824

Received 9th August 2017

Accepted 6th September 2017

DOI: $10.1039 / \mathrm{c} 7 \mathrm{ra0} 0821 \mathrm{c}$

rsc.li/rsc-advances

\section{A hybrid magnetic core-shell fibrous silica nanocomposite for a chemosensor-based highly effective fluorescent detection of $\mathrm{Cu}(\mathrm{II})$}

\author{
K. Radhakrishnan, P. Panneerselvam (D) and A. Ravikumar \\ Herein, a novel hybrid magnetic core-shell fibrous silica nanocomposite ( $\left.\mathrm{RhB}-\mathrm{Fe}_{3} \mathrm{O}_{4} / \mathrm{MnO}_{2} / \mathrm{SiO} / \mathrm{KCC}-1\right)$ \\ probe-based chemosensor was designed and its behaviour towards $\mathrm{Cu}(I)$ metal ion was investigated using \\ a fluorescence spectrometer. The organic receptor rhodamine B (RhB) fluorophore derivative was \\ covalently grafted onto the surface of the magnetic core-shell fibrous silica nanocomposite. This \\ sensing probe achieved the selectivity towards $\mathrm{Cu}(\|)$ in an aqueous solution, and other competing metal \\ ions basically induced no spectral change. Thus, this sensing probe can work as a Cu(॥) selective \\ fluorescent sensor. The synthesized material was characterized using transmission electron microscopy \\ (TEM), scanning electron microscopy-energy dispersive spectroscopy (SEM-EDS), surface analysis (with \\ $B E T)$, Fourier transform infrared spectroscopy (FT-IR), X-ray diffractometry, and thermogravimetric \\ analysis (TGA). The rhodamine $B$ derivative has a unique signalling probe that exhibits a turn-on \\ fluorescence enhancement upon the recognition of $\mathrm{Cu}(॥)$ ion with an excitation at $569 \mathrm{~nm}$. The linearity \\ of the Stern-Volmer plot $\left(R^{2}=0.9882\right)$ and the detection limit of $12.3 \times 10^{-8} \mathrm{M}$ were achieved. Finally, \\ the sensor was tested to detect $\mathrm{Cu}(॥)$ ion in different real water samples.
}

\section{Introduction}

$\mathrm{Cu}(\mathrm{II})$ is one of the most toxic heavy metals. Even at low concentrations, it is a threat to human health and environment due to its high toxicity, mobility, and ability to accumulate through food chains or atmosphere in the ecological system. ${ }^{1}$ Copper(II), as the third most abundant essential trace metal ion in the human body, also plays an important role in various environmental, chemical, and physiological systems. There are many reactions in the biological process that involve the electron transfer that is catalyzed by copper-containing enzymes. ${ }^{2}$ Copper poisoning induces a wide variety of serious complications, such as vomiting, lethargy, increased blood pressure, acute haemolytic anaemia, Meknes and Wilson diseases, neurotoxicity, neurodegenerative, and Alzheimer's and prion diseases, in humans..$^{3-5}$ Additionally, recently, copper has been suspected to cause infant liver damage. Both Indian childhood cirrhosis (ICC) and non-Indian childhood cirrhosis (NICC) have been proven to be associated with an excessive intake of copper ions. ${ }^{6}$ The permissible limit of copper in drinking water set by the US Environmental Protection Agency (EPA) is $1.3 \mathrm{mg} \mathrm{l}^{-1}$ (20 $\mu \mathrm{M}$ ) and that set by the World Health Organization (WHO) is $1.0 \mathrm{mg} \mathrm{l}^{-1}$. Thus, detection of copper in water is of great

Department of Chemistry, SRM University, Kattankulathur-603 203, Chennai, India. E-mail: panneerselvam.pe@ktr.srmuniv.ac.in; panneerchem82@gmail.com; Tel: +91 9688538842 significance due to the wide distribution of copper in the environment and its bioaccumulation through food chain.

Therefore, the interest in developing rapid, specific, and costeffective tools to detect $\mathrm{Cu}(\mathrm{II})$ is steadily growing. ${ }^{8}$ The traditional quantitative methods to develop a $\mathrm{Cu}(\mathrm{II})$ sensor include inductively coupled plasma mass spectroscopy (ICPMS), atomic absorption/emission spectroscopy (AAS/AES), electrochemical detection, and non-material-based probes. ${ }^{9-13}$ However, these methods are time-consuming and require expensive instrumentation, complicated equipment operation etc. Thus, significant efforts have been dedicated towards the development of selective and sensitive detection methods. Among them, fluorescent and colorimetric sensors are the most convenient techniques to monitor the level of copper. The paramagnetic behaviour of $\mathrm{Cu}$ (II), with a $3 \mathrm{~d}^{9}$ outer shell electron configuration, attributes to the quenching of the emission intensity. ${ }^{\mathbf{1 4}}$ With regard to the detection of copper via a fluorescent chemosensor, many previous reports have been focused on the fluorescence quenching process through energy or electron transfer processes. In term of the sensitivity, fluorescence enhancement (turn-on) signals are much easier to detect than fluorescence quenching (turn-off) signals. The rhodamine receptor-based fluorescent chemosensor for the detection of metal cations has received significant attention in recent years by virtue of its excellent spectroscopic properties and good water solubility. It is an ideal moiety to construct turn-on fluorescence chemosensor in term of metal ion triggering the spirolactam ring opening mechanism along with change in chromaticity and fluorescence 
at the same time. Considering the high affinity of $\mathrm{Cu}(\mathrm{II})$ to $\mathrm{N}$ and $\mathrm{O}$ atoms, rhodamine hydrazone is an excellent platform to design a novel fluorescent chemosensor for specially sensing $\mathrm{Cu}(\mathrm{II})$ with high sensitivity in an aqueous solvent. ${ }^{15-19}$

Mesoporous silica materials provide a good support for fluorescence probes due to their unique characteristics such as excellent solvent dispersibility, good optical transparency in the visible region, favourable biocompatibility, large surface area, open pore structure, and abundant functionalization sites in the silica network. ${ }^{20,21}$ Some silica-based mesoporous materials such as SBA-15, MCM-41, and MCM-48 have been reported as inorganic carriers for chemosensor. ${ }^{22-25}$ However, most of these optical nanoprobes have some limitations, which include the requirement of organic or aqueous organic solvent mixtures, poor performance in the removal of metal ions, and poor accessibility of analytes to sensing sites inside the probe. ${ }^{26}$ Therefore, recently, the most promising fibrous silica spheres (KCC-1) have been developed, and they exhibit excellent physical properties such as fibrous surface morphology, thermal and mechanical stability, better sorption capacity, and ease of functionalization of the organic molecule. This valuable material is also used as a catalyst, drug delivery vehicle, chromatography support, and chemosensor. ${ }^{27}$

Herein, we explored a new hybrid nonmaterial that was formed by grafting the functionalized rhodamine B-based receptor onto the inner surface of magnetic core-shell fibrous silica KCC-1. The new hybrid sensor displayed an extremely high selectivity and sensitivity towards $\mathrm{Cu}$ (II) ion as compared to that towards other metal ions. The prepared iron oxide nanoparticles acted as a centre core, and they were then coated with manganese oxide over the surface of silica shell. The $\mathrm{Fe}_{3} \mathrm{O}_{4}$ core was used to saturate the magnetic behaviour, to protect the fluorescence quenching, and to avoid the aggregation of the nanocomposite. This approach has improved the selectivity and enhancement of fluorescence signal, as depicted in Scheme 1. Finally, the developed sensing system was successfully utilized for the detection of $\mathrm{Cu}$ (II) ion in environmental water samples. The design strategy of the hybrid sensor I is such that the recovery and reusability of the sensing material can be achieved. To the best of our knowledge, this is the first time that the detection of $\mathrm{Cu}(\mathrm{II})$ ion using an $\mathrm{Fe}_{3} \mathrm{O}_{4} /$ $\mathrm{MnO}_{2}$ magnetic nanocomposite on a fibrous silica core functionalized with a rhodamine-based derivative has been reported.

\section{Experimental}

\subsection{Reagents and instruments}

All chemicals were obtained from the commercial source and used without further purification. Unless otherwise stated, all chemicals were of analytical reagent grade. Rhodamine B, 5chlorosalicylic aldehyde, ethylenediamine, cyclohexane, $n$-pentanol, tetraethoxysilane (TEOS), cetylpyridinium bromide (CPB), and 3-aminopropyltriethoxysilane (APTES) were purchased from Alfa-Aesar. Salts used in the stock solutions of metal ions were $\mathrm{KNO}_{3}, \mathrm{AgNO}_{3}, \mathrm{Ca}\left(\mathrm{NO}_{3}\right)_{2} \cdot 4 \mathrm{H}_{2} \mathrm{O}, \mathrm{Ni}\left(\mathrm{NO}_{3}\right) \cdot 6 \mathrm{H}_{2} \mathrm{O}, \mathrm{Hg}\left(\mathrm{NO}_{3}\right)_{2}{ }^{-}$ $\cdot \mathrm{H}_{2} \mathrm{O}, \mathrm{Pb}\left(\mathrm{NO}_{3}\right)_{2}, \mathrm{Zn}\left(\mathrm{NO}_{3}\right)_{2} \cdot 6 \mathrm{H}_{2} \mathrm{O}, \mathrm{Co}\left(\mathrm{NO}_{3}\right)_{2} \cdot 6 \mathrm{H}_{2} \mathrm{O}, \mathrm{Al}\left(\mathrm{NO}_{3}\right)_{2}-$ $\cdot 9 \mathrm{H}_{2} \mathrm{O}$, and $\mathrm{Fe}\left(\mathrm{NO}_{3}\right)_{3} \cdot 9 \mathrm{H}_{2} \mathrm{O}$. They were purchased from SigmaAldrich (India). All other organic solvents such as ethanol, toluene, dichloromethane, and ethyl acetate used in this study were obtained from Siscon research laboratories Pvt. Ltd (India) and purified by a standard procedure.

Transmission electron microscopy (TEM) analysis was performed using JEOL/JEM 2100. For the sample preparation, the powders were dispersed in ethanol, and the suspension was dropped onto a 200 mesh carbon-coated TEM grid. The morphologies of the as-prepared samples were investigated using the field emission scanning electron microscope (FESEM) FEI Quanta FEG200. X-Ray diffraction (XRD) measurements were carried out via a PAN analytical X'pert powder diffractometer using $\mathrm{Cu}-\mathrm{K} \alpha$ radiation $(\lambda=0.15405 \AA)$. Fourier transform infrared (FT-IR) spectra were obtained using an Agilent Resolution Pro FT-IR spectrometer. The surface area was measured using a smart sorbs 92 surface area analyser, and $\mathrm{N}_{2}$ was used as an adsorbate. Thermogravimetric analysis (TGA, STA 2500 Regulus, NETZSCH) was performed at a heating rate of $10{ }^{\circ} \mathrm{C} \mathrm{min}{ }^{-1}$, and the nitrogen flow was $10 \mathrm{ml} \mathrm{min}{ }^{-1}$. The magnetization property of the sample was measured using a vibrating sample magnetometer (Lakeshore VSM 7410). Fluorescence spectra of the sample were obtained using a HORIBA JOBIN YVON Fluoromax-4 spectrofluorometer with a xenon lamp excitation source. The UV-vis absorption spectra were obtained using a Shimadzu UV-2600 spectrophotometer. All $\mathrm{pH}$ values were obtained using a PHS-3C digital $\mathrm{pH}$ meter.

\subsection{Preparation of the $\mathrm{Fe}_{3} \mathrm{O}_{4} / \mathrm{MnO}_{2} / \mathrm{SiO}_{2}$ nanocomposite}

The $\mathrm{Fe}_{3} \mathrm{O}_{4} / \mathrm{MnO}_{2}$ nanocomposite was prepared by a simple hydrothermal process following the procedure reported in the literature. ${ }^{28}$ In a typical preparation, $0.51 \mathrm{~g}$ of $\mathrm{KMnO}_{4}$ was dissolved in $35 \mathrm{ml}$ of deionized water and $0.7 \mathrm{ml}$ of $\mathrm{HCl}(37 \mathrm{wt} \%)$ under stirring for 15 minutes. To this mixture, $0.3 \mathrm{~g}$ of $\mathrm{Fe}_{3} \mathrm{O}_{4}$ was added, and the mixture was continuously stirred for another $30 \mathrm{~min}$. Then, the mixture was transferred to a $50 \mathrm{ml}$ Teflon-lined autoclave that was kept in an oven at $120^{\circ} \mathrm{C}$ for $6 \mathrm{~h}$ for hydrothermal treatment under a static condition. The required product was obtained by applying an external magnet, washed several times with ethanol and deionized water, and then dried at $60{ }^{\circ} \mathrm{C}$. The abovementioned prepared $\mathrm{Fe}_{3} \mathrm{O}_{4} / \mathrm{MnO}_{2}$ nanocomposite was dispersed in $30 \mathrm{ml}$ ethanol and deionized water, and the mixture was stirred with $0.7 \mathrm{ml}$ of concentrated ammonia solution using a magnetic stirrer. After this, $0.2 \mathrm{~g}$ of TEOS was added dropwise, and the mixture was continuously stirred at room temperature for $6 \mathrm{~h}$. Finally, the resulting product $\mathrm{Fe}_{3} \mathrm{O}_{4} / \mathrm{MnO}_{2} / \mathrm{SiO}_{2}$ nanocomposite was separated via an external magnetic field and washed several times with deionized water.

\subsection{Preparation of $\mathrm{Fe}_{3} \mathrm{O}_{4} / \mathrm{MnO}_{2} / \mathrm{SiO}_{2} / \mathrm{KCC}-1$}

For the facile synthesis of $\mathrm{Fe}_{3} \mathrm{O}_{4} / \mathrm{MnO}_{2} / \mathrm{SiO}_{2} / \mathrm{KCC}-1,0.3 \mathrm{~g}$ of $\mathrm{Fe}_{3} \mathrm{O}_{4} / \mathrm{MnO}_{2} / \mathrm{SiO}_{2}$ was first mixed with distilled water and ultrasonicated for $30 \mathrm{~min}$. Then, $0.3 \mathrm{~g}$ of urea dissolved in $20 \mathrm{ml}$ of water was added dropwise to the solution and ultrasonicated for $20 \mathrm{~min}$. Subsequently, $0.5 \mathrm{~g}$ of CPB dissolved in $0.7 \mathrm{ml}$ of $n$ pentanol and $30 \mathrm{ml}$ of cyclohexane was added slowly under stirring at room temperature. TEOS $(1.25 \mathrm{~g}, 6.0 \mathrm{mmol})$ was added dropwise to the mixture and it was stirred for $1 \mathrm{~h}$. Then, 

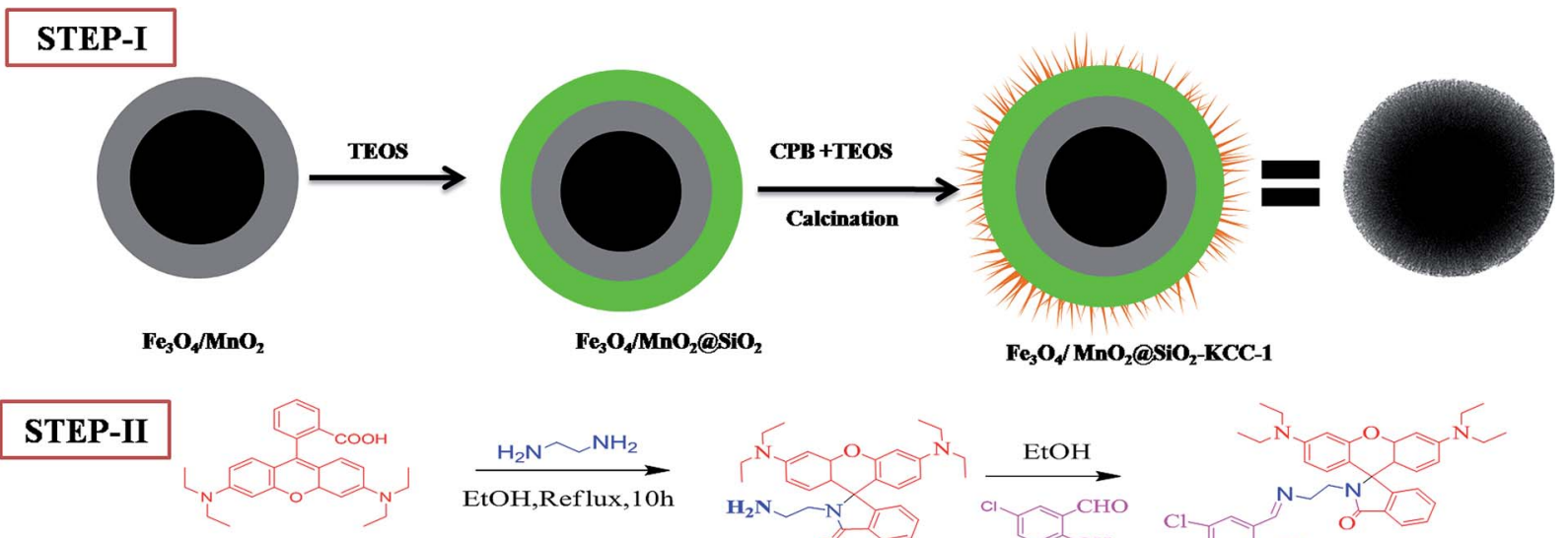

Rhodamine B

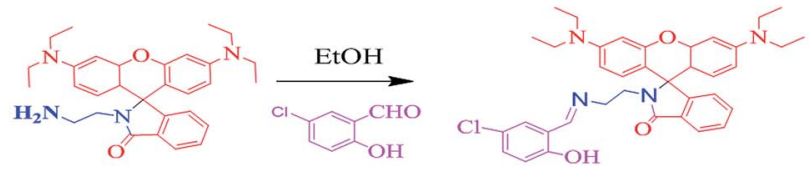

Rhodamine B- $\mathrm{NH}_{2}$

RhB-5-Chlorosalicylaldehyde

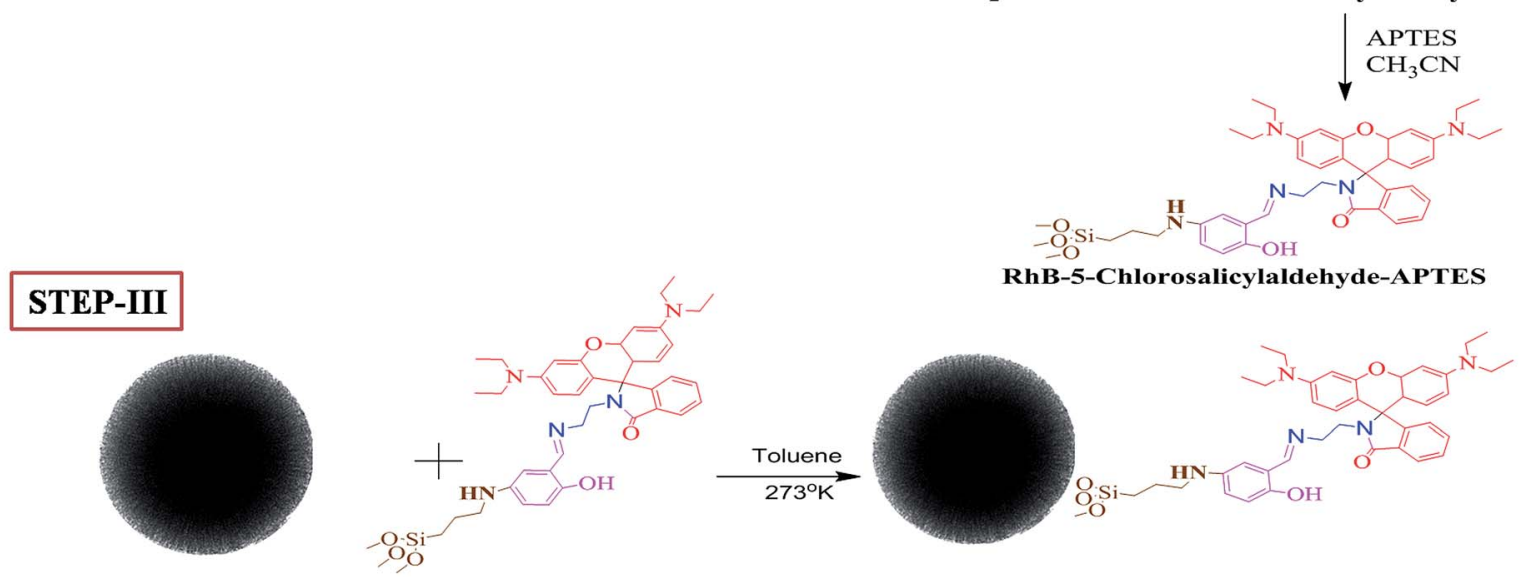

$\mathrm{Fe}_{3} \mathrm{O}_{4} / \mathrm{MnO}_{2} / \mathrm{SiO}_{2} / \mathrm{KCC}-1$

RhB-5-Chlorosalicylaldehyde-APTES

$\mathrm{RhB}^{-\mathrm{Fe}_{3}} \mathrm{O}_{4} / \mathrm{MnO}_{2} / \mathrm{SiO}_{2} / \mathrm{KCC}-1$

(Hybrid Sensor I)

\section{Sensing Mechanism}
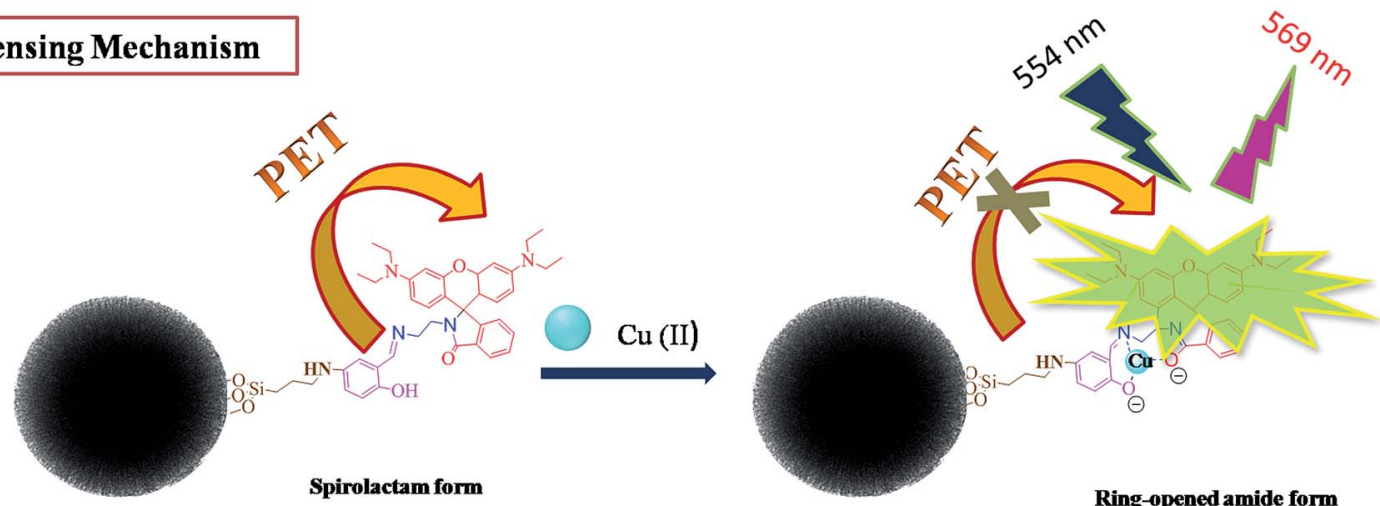

Scheme 1 Schematic of the design and turn-on fluorescence mechanism for $\mathrm{Cu}(\mathrm{I})$ sensing.

the reaction mixture was kept in an autoclave at $120^{\circ} \mathrm{C}$ for $6 \mathrm{~h}$. The obtained nanocomposite was separated by a strong magnet, washed sequentially with water and acetone, and then dried overnight at $60{ }^{\circ} \mathrm{C}$. Finally, the prepared hybrid silica nanocomposite material was calcined at $550{ }^{\circ} \mathrm{C}$ for $6 \mathrm{~h}$.

\subsection{Preparation of $\mathrm{RhB}-\mathrm{NH}_{2}$}

The preparation of $\mathrm{RhB}-\mathrm{NH}_{2}$ was carried out using the previously reported method. ${ }^{29}$ First, rhodamine B (3.82 g, $\left.8 \mathrm{mmol}\right)$ and ethane-1,2-diamine $(2.6 \mathrm{ml}, 40 \mathrm{mmol})$ were dissolved in
$100 \mathrm{ml}$ of ethanol and refluxed for $8 \mathrm{~h}$. After this, the reaction mixture was cooled down to room temperature, and then, the solvent was removed under vacuum. Finally, the resultant product was obtained and washed with $\mathrm{CH}_{2} \mathrm{Cl}$. The organic layer was dried over anhydrous magnesium sulphate.

\subsection{Preparation of RhB-5-chlorosalicylaldehyde-APTES}

Typically, $0.46 \mathrm{~g}$ of $\mathrm{RhB}-\mathrm{NH}_{2}$ was dissolved in $30 \mathrm{ml}$ of ethanol and $4 \mathrm{mmol}$ of 5-chlorosalicyladehyde was added dropwise to the solution. The mixture was refluxed for $8 \mathrm{~h}$ and allowed to 
cool down to room temperature. To the mixture, $10 \mathrm{ml}$ of ethyl acetate was added, and then, the mixture was kept in a refrigerator overnight. The material was washed with distilled water followed by ethanol and dried at $65{ }^{\circ} \mathrm{C}$. After the resulting material RhB-5-chlorosalicylaldehyde $(0.270 \mathrm{~g}, 1.0 \mathrm{mmol})$ was obtained and reacted with $(0.241 \mathrm{~g}, 0.1 \mathrm{mmol})$ APTES, $\mathrm{K}_{2} \mathrm{CO}_{3}$ $(0.138 \mathrm{~g}, 1.0 \mathrm{mmol})$ in $30 \mathrm{ml}$ acetonitrile was slowly added to the solution mixture that was then refluxed for $8 \mathrm{~h}$. Finally, the product was purified by column chromatography with ethyl acetate : hexane solvent.

\subsection{Synthesis of $\mathrm{RhB}-\mathrm{Fe}_{3} \mathrm{O}_{4} / \mathrm{MnO}_{2} / \mathrm{SiO}_{2} / \mathrm{KCC}-1$}

In a typical synthesis, $200 \mathrm{mg}$ of $\mathrm{Fe}_{3} \mathrm{O}_{4} / \mathrm{MnO}_{2} / \mathrm{SiO}_{2} / \mathrm{KCC}-1$ was dissolved in $40 \mathrm{ml}$ of toluene, and $200 \mathrm{mg}$ of $\mathrm{RhB}-\mathrm{Si}$ was added. The mixture was stirred for $12 \mathrm{~h}$ under a nitrogen atmosphere. The resulting product was separated by a strong magnet and washed several times with $30 \mathrm{ml}$ of different solvents, including toluene, dichloromethane, and ethanol, each time. The purified product was dried at $60{ }^{\circ} \mathrm{C}$ and then used for further analysis.

\section{Results and discussion}

\subsection{Design and analysis of the hybrid sensor}

The synthesis of rhodamine-based receptor and functionalized mesoporous magnetic core-shell fibrous silica KCC-1 involves several steps, as outlined in Scheme 1. The main aim of this study was to identify the ability of the hybrid sensor I towards the detection of $\mathrm{Cu}(\mathrm{II})$ ion over other metal ions and the recovery of this sensor. To achieve an effective sensing system, the design of multicore-shell is architectured in a way that paramagnetic microspheres of iron oxide core $\left(\mathrm{Fe}_{3} \mathrm{O}_{4}\right)$ are deposited with nanosized manganese oxide $\left(\mathrm{MnO}_{2}\right)$ to prevent aggregation and dipole interaction between magnetic nanoparticles. It is found that $\mathrm{Fe}_{3} \mathrm{O}_{4}$ provides an effortless magnetic separation and increases the durability of the material. The modified deposited $\mathrm{MnO}_{2}$ nanoparticles have a high acid etching resistance, are stable in organic solvents such as methanol, and also closely interact with $\mathrm{Fe}_{3} \mathrm{O}_{4} \cdot{ }^{30,31}$ To avoid the solubility of the core-shell $\mathrm{Fe}_{3} \mathrm{O}_{4} / \mathrm{MnO}_{2}$ in water, a multistep strategy is engaged to deposit dense silica on the surface. $\mathrm{SiO}_{2}$ provides stability to the inner core, and its uniform surface supports the growth of fibrous silica. Very importantly, the thickness of the fabricated silica prevents the fluorescence energy transfer process (FRET) between the magnetic core-shell and the fluorophore. ${ }^{32}$ Finally, the nanocomposite $\left(\mathrm{Fe}_{3} \mathrm{O}_{4} / \mathrm{MnO}_{2} / \mathrm{SiO}_{2}\right)$ is modified with fibrous silica on the outer surface. The fibrous mesoporous silica surface could be easily functionalized with a silane reagent (APTES), on the surface moieties, such that sensing molecules of rhodamine B derivatives are uniformly covered on the silica surface. The functionalized modified nanocomposite is a suitable solid base material with a better dispersibility. The importance of this hybrid sensor I is that it has electron rich species, such as carbonyl $(\mathrm{O})$, imino $(\mathrm{N})$, and phenol $(\mathrm{O})$ atoms, which effectively and selectively binding with $\mathrm{Cu}$ (II) over other metal ions. The spirolactam ring-opening upon binding with cation to enhance the fluorescence is a special feature of the hybrid sensor I to create a barrier for quenching and improving the sensing performance of $\mathrm{Cu}(\mathrm{II})$.

\subsection{Characterization}

The morphology of the hybrid magnetic core-shell fibrous silica nanocomposite was observed by SEM and TEM, as shown in Fig. 1a-f. The $\mathrm{Fe}_{3} \mathrm{O}_{4}$ nanoparticles exhibited a spherical shape with a diameter of about $480 \mathrm{~nm}$ (Fig. 1a). After coating by amorphous $\mathrm{MnO}_{2}$, the average diameter of $\mathrm{Fe}_{3} \mathrm{O}_{4} / \mathrm{MnO}_{2}$

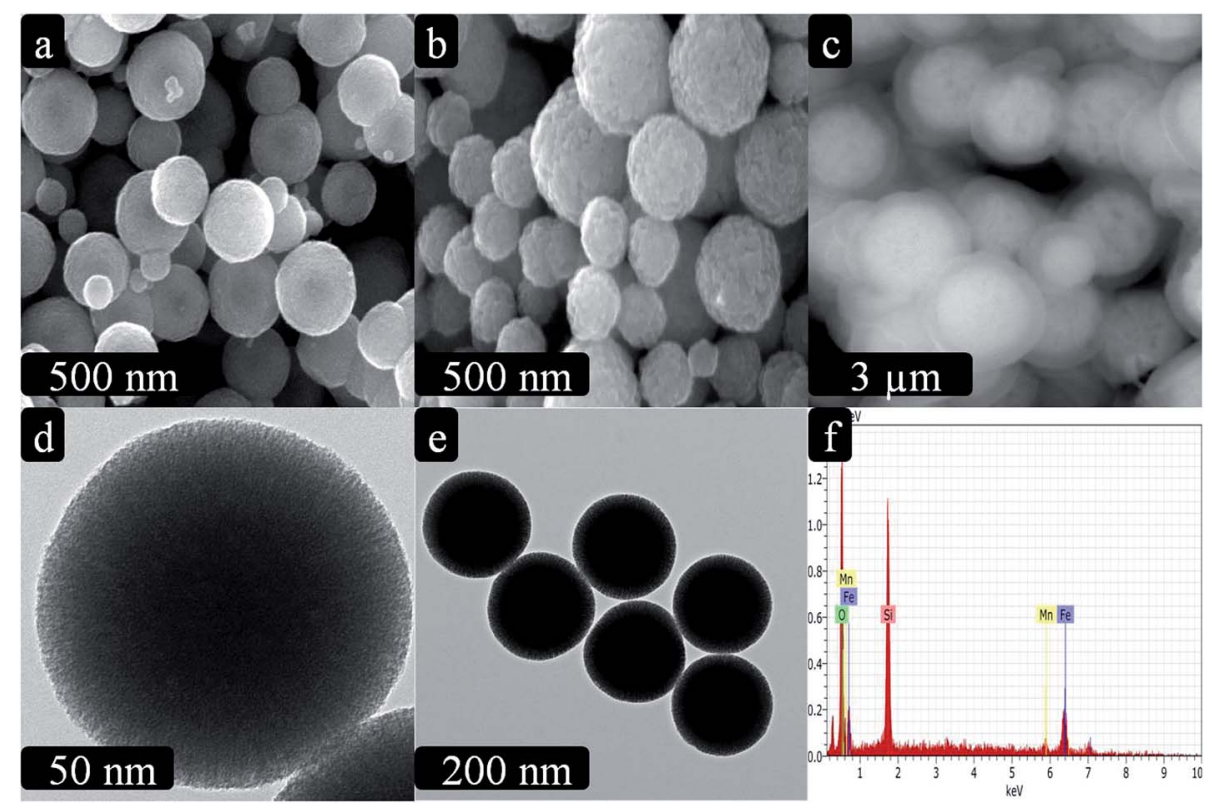

Fig. 1 SEM images of (a) $\mathrm{Fe}_{3} \mathrm{O}_{4}$, (b) $\mathrm{Fe}_{3} \mathrm{O}_{4} / \mathrm{MnO}_{2}$, and (c) $\mathrm{Fe}_{3} \mathrm{O}_{4} / \mathrm{MnO}_{2} / \mathrm{SiO}_{2} / \mathrm{KCC}-1$. TEM images of (d) $\mathrm{KCC}-1$ and (e) $\mathrm{Fe} \mathrm{O}_{4} / \mathrm{MnO}_{2} / \mathrm{SiO} 2 / \mathrm{KCC}-1$. (f) Elemental analysis of the $\mathrm{Fe}_{3} \mathrm{O}_{4} / \mathrm{MnO}_{2} / \mathrm{SiO}_{2} / \mathrm{KCC}-1$ nanocomposite. 
nanocomposite increased to $620 \mathrm{~nm}$. This clearly indicates that uniform and well-dispersed spherical structures were formed without aggregation (Fig. 1b). After this, successful coating of magnetic nanocomposite with fibrous silica was clearly observed in Fig. 1c. Furthermore, in the TEM images (Fig. 1d and e), the fibrous structure of the parent KCC- 1 clearly shows the unique fibrous surface with a spherical shape (Fig. 1d). As shown in Fig. 1e, the inner surface clearly shows the core shell modification $\left(\mathrm{Fe}_{3} \mathrm{O}_{4} / \mathrm{MnO}_{2} / \mathrm{SiO}_{2} / \mathrm{KCC}-1\right)$ compared to that of parent KCC-1. In Fig. 1e, the black inner surface in the coreshell is represented by $\mathrm{Fe}_{3} \mathrm{O}_{4} / \mathrm{MnO}_{2}$ and gray-coloured outer surface is represented by fibrous silica that is covered all over the surface. The EDS elemental analysis of fibrous silica $\mathrm{Fe}_{3} \mathrm{O}_{4} /$ $\mathrm{MnO}_{2} / \mathrm{SiO}_{2} / \mathrm{KCC}-1$ exhibited the presence of $\mathrm{Fe}, \mathrm{Mn}, \mathrm{Si}$, and $\mathrm{O}$ (Fig. 1f), further indicating the formation of the hybrid coreshell magnetic fibrous silica nanocomposite.

The X-ray diffraction (XRD) pattern was obtained to investigate the formation of $\mathrm{Fe}_{3} \mathrm{O}_{4} / \mathrm{MnO}_{2}$ and $\mathrm{Fe}_{3} \mathrm{O}_{4} / \mathrm{MnO}_{2} / \mathrm{SiO}_{2} / \mathrm{KCC}$ 1. As shown in Fig. 2a, the characteristic diffraction peaks of the magnetic nanocomposite located at $30.17^{\circ}, 35.51^{\circ}, 43.10^{\circ}$, $53.75^{\circ}, 57.32^{\circ}$, and $62.89^{\circ}$ can be attributed to the (220), (311), (400), (422), (511), and (440) crystal planes, respectively, which represent the inverse spinal structure of $\mathrm{Fe}_{3} \mathrm{O}_{4}$ nanoparticles (JCPDS card no. 19-0629). ${ }^{33}$ Moreover, the well-resolved diffraction peaks at around $28.6^{\circ}$ and $37.3^{\circ}$ indicated the presence of $\mathrm{MnO}_{2} \cdot{ }^{34}$ As displayed in Fig. $2 \mathrm{~b}$, the broad diffraction peak at around $22.48^{\circ}$ indicated the growth of fibrous silica on the surface of $\mathrm{Fe}_{3} \mathrm{O}_{4} / \mathrm{MnO}_{2}$ nanocomposite. ${ }^{35}$

FT-IR analysis has been performed on $\mathrm{Fe}_{3} \mathrm{O}_{4} / \mathrm{MnO}_{2} / \mathrm{SiO}_{2} /$ KCC-1 and the hybrid sensor I. As shown in Fig. 3a, the absorption band at $563.2 \mathrm{~cm}^{-1}$ is assigned to the $\mathrm{Fe}-\mathrm{O}-\mathrm{Fe}$ stretching and bending mode, and no characteristic peaks for the amorphous $\mathrm{MnO}_{2}$ are observed. The vibration peaks of fibrous mesoporous silica at $467.4 \mathrm{~cm}^{-1}, 809.3 \mathrm{~cm}^{-1}$, and $1092.5 \mathrm{~cm}^{-1}$ are assigned to the symmetric and asymmetric stretching of the Si-O-Si bonds. The strong absorption peak at $3426.5 \mathrm{~cm}^{-1}$ is assigned to the hydroxyl groups. As shown in Fig. 3b, new bands at $2856.4 \mathrm{~cm}^{-1}, 2925.9 \mathrm{~cm}^{-1}$, and

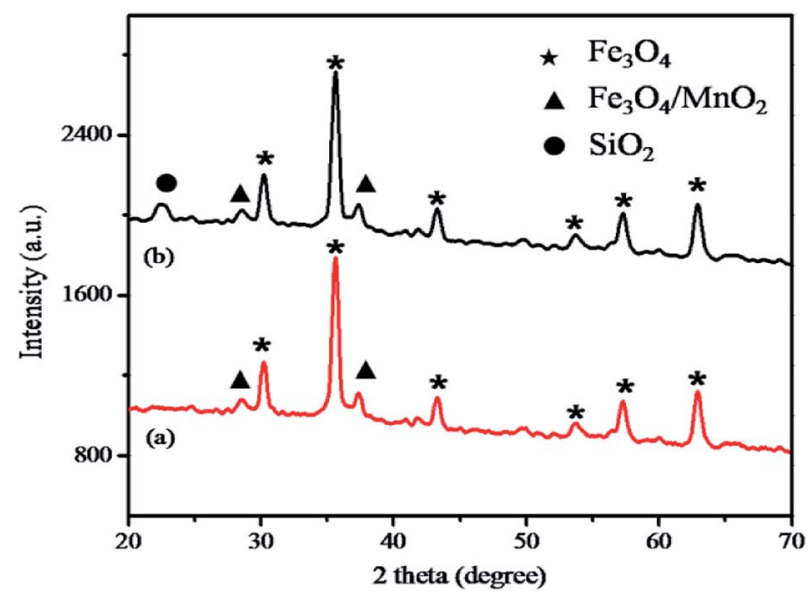

Fig. $2 \mathrm{X}$-ray diffraction patterns of (a) $\mathrm{Fe}_{3} \mathrm{O}_{4} / \mathrm{MnO}_{2}$ and (b) $\mathrm{Fe}_{3} \mathrm{O}_{4} /$ $\mathrm{MnO}_{2} / \mathrm{SiO}_{2} / \mathrm{KCC}-1$.

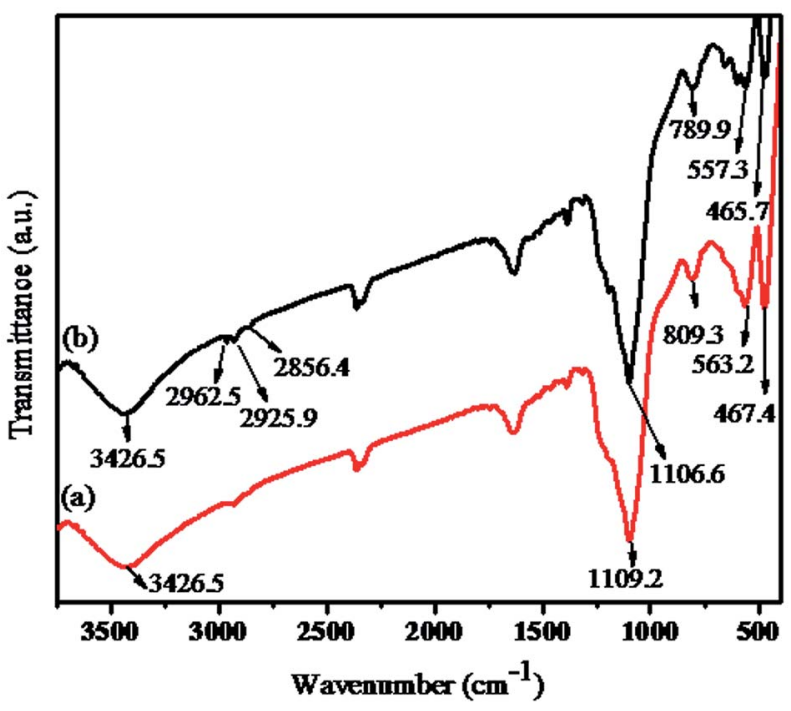

Fig. 3 FT-IR spectra of (a) $\mathrm{Fe}_{3} \mathrm{O}_{4} / \mathrm{MnO}_{2} / \mathrm{SiO}_{2} / \mathrm{KCC}-1$ and (b) RhB$\mathrm{Fe}_{3} \mathrm{O}_{4} / \mathrm{MnO}_{2} / \mathrm{SiO}_{2} / \mathrm{KCC}-1$.

$2962.5 \mathrm{~cm}^{-1}$ can be assigned to the stretching vibration of methylene and amide group, ${ }^{36,37}$ which confirm that rhodamine B derivatives have been functionalized with hybrid core-shell magnetic fibrous silica nanocomposite.

Nitrogen adsorption/desorption isotherm reveals the surface modification for the hybrid sensor I. Upon investigation, it was observed that the magnetic nanocomposite and rhodaminefunctionalized nanocomposite showed a modified textural property and surface area, as shown in Fig. 4. For the $\mathrm{Fe}_{3} \mathrm{O}_{4} /$ $\mathrm{MnO}_{2} / \mathrm{SiO}_{2} / \mathrm{KCC}-1$ and $\mathrm{RhB}-\mathrm{Fe}_{3} \mathrm{O}_{4} / \mathrm{MnO}_{2} / \mathrm{SiO}_{2} / \mathrm{KCC}-1$ nanocomposite, the BET surface area was 225.08 and $69.25 \mathrm{~m}^{2} \mathrm{~g}^{-1}$, the pore diameter was 7.96 and $6.74 \mathrm{~nm}$, and the pore volume was 0.56 and $0.13 \mathrm{~cm} \mathrm{~g}^{-1}$, respectively. These results describe the effective functionalization of the organic probe on the surface of the fibrous nanocomposite.

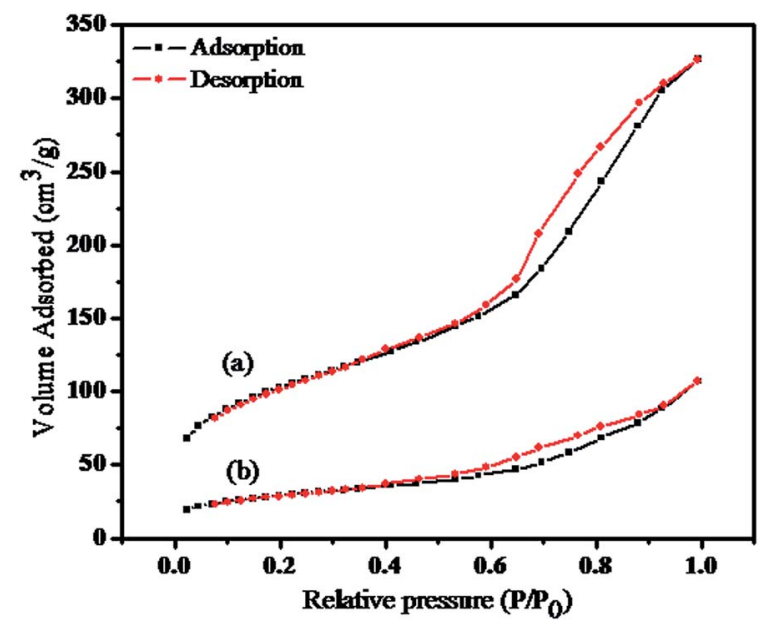

Fig. 4 The nitrogen adsorption-desorption isotherms of (a) $\mathrm{Fe}_{3} \mathrm{O}_{4} /$ $\mathrm{MnO}_{2} / \mathrm{SiO}_{2} / \mathrm{KCC}-1$ and (b) $\mathrm{RhB}-\mathrm{Fe}_{3} \mathrm{O}_{4} / \mathrm{MnO}_{2} / \mathrm{SiO}_{2} / \mathrm{KCC}-1$. 


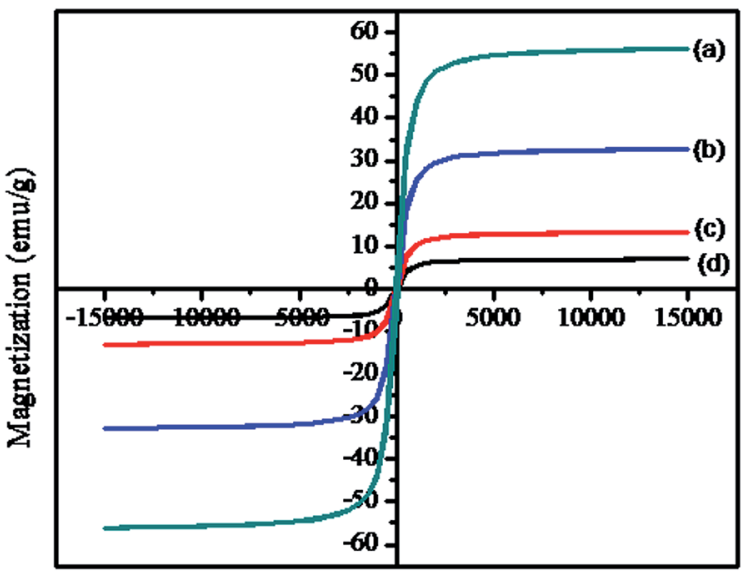

Magnetic field (Oe)

Fig. 5 Magnetization curves of (a) $\mathrm{Fe}_{3} \mathrm{O}_{4}$, (b) $\mathrm{Fe}_{3} \mathrm{O}_{4} / \mathrm{MnO}_{2}$, (c) $\mathrm{Fe}_{3} \mathrm{O}_{4} /$ $\mathrm{MnO}_{2} / \mathrm{SiO}_{2} / \mathrm{KCC}-1$, and (d) $\mathrm{RhB}-\mathrm{Fe}_{3} \mathrm{O}_{4} / \mathrm{MnO}_{2} / \mathrm{SiO}_{2} / \mathrm{KCC}-1$. The inset image shows the magnetic separation behaviour of the hybrid sensor I.

As shown in Fig. 5a-d, the magnetic measurements of pristine $\mathrm{Fe}_{3} \mathrm{O}_{4}, \mathrm{Fe}_{3} \mathrm{O}_{4} / \mathrm{MnO}_{2}, \mathrm{Fe}_{3} \mathrm{O}_{4} / \mathrm{MnO}_{2} / \mathrm{SiO}_{2} / \mathrm{KCC}-1$, and the hybrid sensor I were 56.09, 32.6, 13.0, and $6.9 \mathrm{emu} \mathrm{g}^{-1}$, respectively. All samples exhibited super paramagnetic behaviour at room temperature. The magnetic saturation value decreased from Fig. $5 \mathrm{a}$ to d due to the increase in the diameter of the outer surface of $\mathrm{Fe}_{3} \mathrm{O}_{4}$ nanoparticles and the presence of the organic molecule. As a result, the functionalized core-shell nanocomposite can rapidly redisperse and prevent the aggregation of nanoparticles. It can be observed that the hybrid sensor I can be homogeneously dispersed in different solvents and rapidly separated within $1 \mathrm{~min}$ by an external magnet, as illustrated in the inset of Fig. 5. In addition, the saturated magnetic behaviour of the hybrid sensor I acted as an effective barrier to the quenching fluorophore.

The stability of the hybrid sensor I was determined by TGA measurements in the temperature range from 50 to $615{ }^{\circ} \mathrm{C}$ at

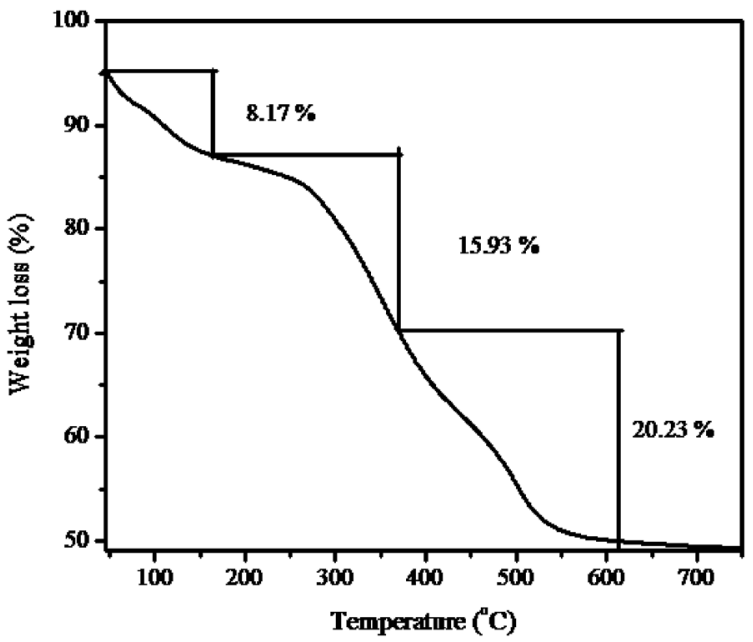

Fig. 6 TGA data of $\mathrm{RhB}-\mathrm{Fe}_{3} \mathrm{O}_{4} / \mathrm{MnO}_{2} / \mathrm{SiO}_{2} / \mathrm{KCC}-1$. a heating rate of $10{ }^{\circ} \mathrm{C} \min ^{-1}$ under a nitrogen atmosphere. As shown in Fig. 6, the curve exhibits three-step weight loss over the temperature ranges of $50-165{ }^{\circ} \mathrm{C}, 166-367{ }^{\circ} \mathrm{C}$, and $368-$ $615{ }^{\circ} \mathrm{C}$. The first weight loss of $8.17 \%$ was predominantly due to the removal of physically absorbed water and organic solvent. The second weight loss of $15.93 \%$ was attributed to the thermal decomposition of functionalized organic compounds. The final weight loss of $20.23 \%$ was due to the complete decomposition of the whole nanocomposite. Total weight loss was about $44.86 \%$ in the temperature range from 50 to $615{ }^{\circ} \mathrm{C}$. The TGA results of the hybrid sensor I demonstrate that it has a superior thermal stability at high temperatures.

\subsection{Sensing performance}

3.3.1. Absorption response for the detection of $\mathrm{Cu}(\mathrm{II})$ ion. To optimize the sensing ability of the hybrid sensor I, $\mathrm{CH}_{3} \mathrm{CN} /$ water solution $(1: 1, \mathrm{v} / \mathrm{v})$ was preferred for $\mathrm{UV}$-vis detection process. After the addition of various metal ions $(\mathrm{K}(\mathrm{I}), \operatorname{Ag}(\mathrm{I})$, $\mathrm{Ca}(\mathrm{II}), \mathrm{Ni}(\mathrm{II}), \mathrm{Hg}$ (II), $\mathrm{Pb}$ (II), $\mathrm{Zn}$ (II), $\mathrm{Co}(\mathrm{II}), \mathrm{Ba}(\mathrm{II}), \mathrm{Fe}(\mathrm{II})$, and $\mathrm{Cd}(\mathrm{II})$ ) in the form of their nitrates, only copper ion showed a higher response than other metal ions such as $\mathrm{Fe}(\mathrm{II})$ and $\mathrm{Co}(\mathrm{II})$, as shown in Fig. 7c. Upon increasing the concentration of $\mathrm{Cu}$ (II) ion in the solution in the range of $0-5 \times 10^{-4} \mathrm{M}$, the hybrid sensor I turned from colourless to pink with a significant enhancement of a new absorbance peak centred at $556 \mathrm{~nm}$, and a smaller peak at $522 \mathrm{~nm}$ was obtained. This proves the selectivity of $\mathrm{Cu}(\mathrm{II})$ ion towards the binding site. The significant appearance of colour and the enhancement of absorbance peak indicate the ringopened amide form of the probe. ${ }^{38}$ These results indicate that the hybrid sensor I can be used for the rapid determination of $\mathrm{Cu}(\mathrm{II})$ by the naked eye. The titration for $\mathrm{Cu}(\mathrm{II})$ concentration variation showed a better linear relationship $\left(R^{2}=0.9838\right)$, as shown in Fig. 7b. The detection limit was found to be $26.40 \mathrm{nM}$. The data obtained from the Stern-Volmer plot suggested that the synthesized material had a good selectivity for $\mathrm{Cu}$ (II) ion.

3.3.2. Emission response for the detection of $\mathbf{C u}(\mathrm{II})$. The fluorescence spectra of the hybrid sensor I have been used to recognize the sensing behaviour and the molecular interaction towards $\mathrm{Cu}(\mathrm{II})$. To identify the sensitivity of the process, interrelated parameters in the sensing ability were analyzed. The fluorescence titration of the hybrid sensor $\mathrm{I}\left(0.1 \mathrm{mg} \mathrm{ml}^{-1}\right)$ in $\mathrm{CH}_{3} \mathrm{CN} /$ water $(1: 1, \mathrm{v} / \mathrm{v}$ ) system was carried out with $\mathrm{Cu}(\mathrm{II})$ in the concentration range of $0-5 \times 10^{-4} \mathrm{M}$. As shown in Fig. 8a, the emission band of the hybrid sensor I ( $5 \mu \mathrm{M})$ exhibited a weak fluorescence at $569 \mathrm{~nm}\left(\lambda_{\mathrm{ex}} 520 \mathrm{~nm}\right)$, which was attributed to the close ring spirolactam form of the probe with a photo induced electron-transfer (PET) process that was induced by nitrogen atoms bonded to a hydrogen atom. The fluorescence emission intensity was enhanced around $569 \mathrm{~nm}$ with the increase in $\mathrm{Cu}$ (II) ion concentration. The rhodamine derivative coordinated with $\mathrm{Cu}(\mathrm{II})$; this led to the spirolactam ring-untie mechanism, ${ }^{39,40}$ which was associated with a switch on UV-vis spectral response at $556 \mathrm{~nm}$ and the emission response at $569 \mathrm{~nm}$.

The Stern-Volmer plot, which expresses the linear relationship between $F_{0} / F$ values (where $F_{0}$ and $F$ indicate the presence and absence of $\mathrm{Cu}$ (II) ion at $569 \mathrm{~nm}$ ) and the $\mathrm{Cu}$ (II) 

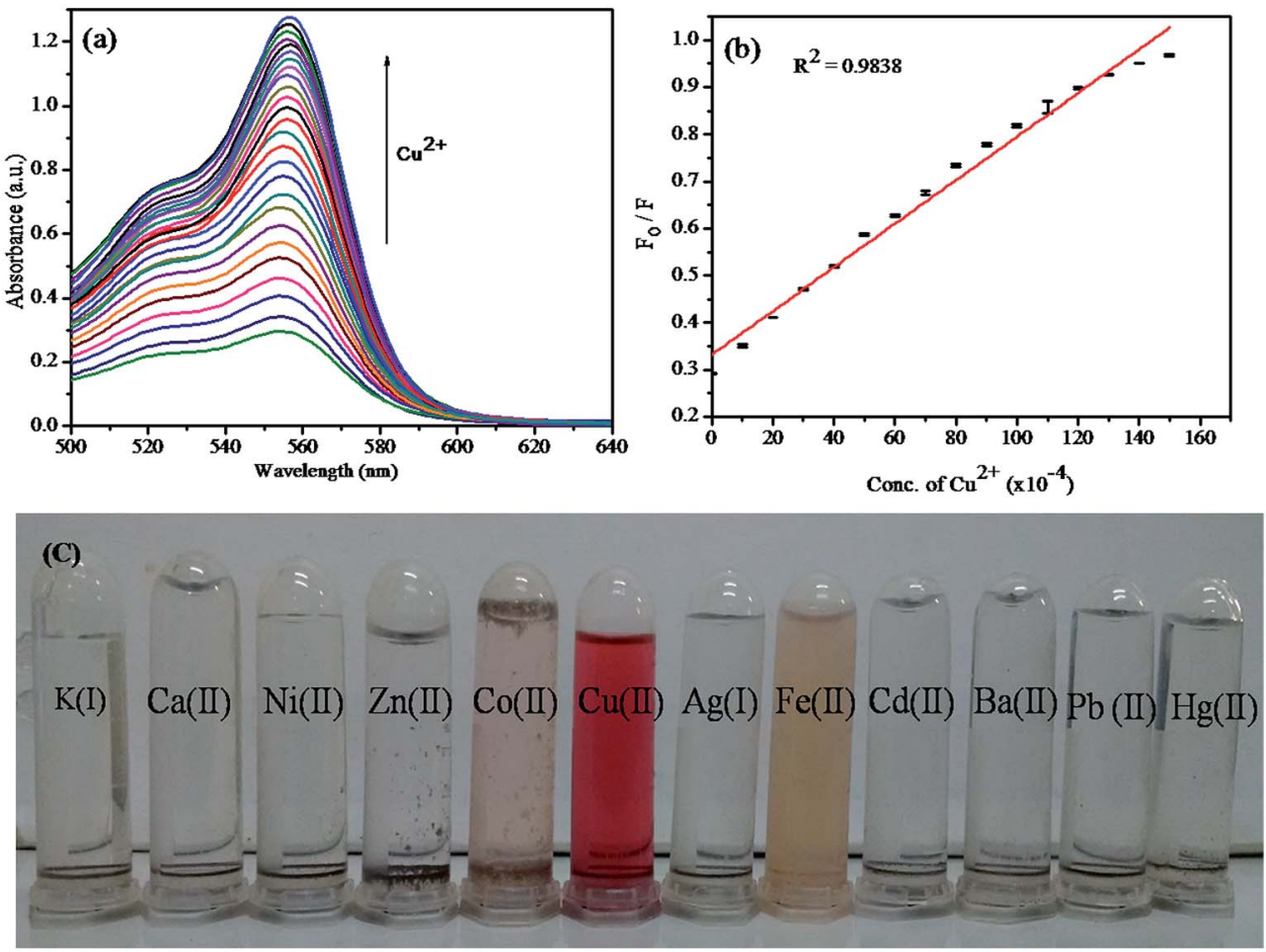

Fig. 7 (a) Absorption spectra of $\mathrm{RhB}-\mathrm{Fe}_{3} \mathrm{O}_{4} / \mathrm{MnO}_{2} / \mathrm{SiO}_{2} / \mathrm{KCC}-1\left(0.4 \mathrm{mg} \mathrm{ml}^{-1}\right)$ in $\mathrm{CH}_{3} \mathrm{CN} / \mathrm{H}_{2} \mathrm{O}(1: 1$, v/v) and different concentrations of Cu(॥) (0$5 \times 10^{-4} \mathrm{M}$ ). (b) The Stern-Volmer plot between various concentrations of $\mathrm{Cu}(\mathrm{II})$ ion and $\mathrm{F}_{0} / \mathrm{F}$ values. (c) Image of $\mathrm{RhB}-\mathrm{Fe}_{3} \mathrm{O}_{4} / \mathrm{MnO}_{2} / \mathrm{SiO} / 2 / \mathrm{KCC}-1$

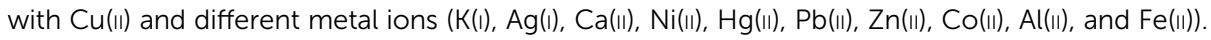
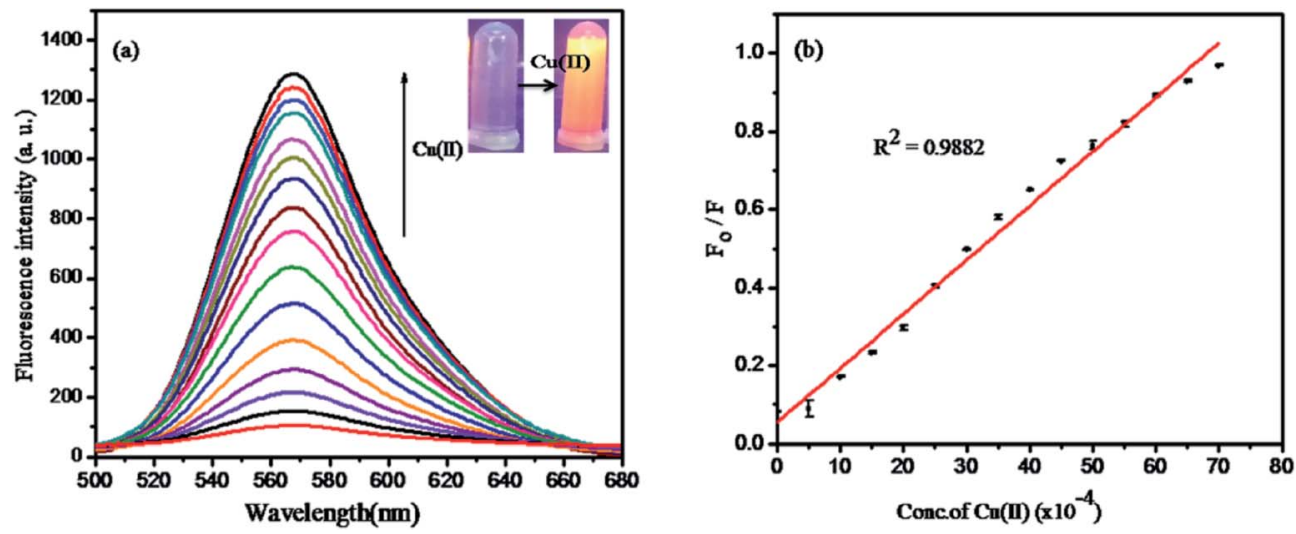

Fig. 8 (a) Fluorescence spectra of $\mathrm{RhB}-\mathrm{Fe}_{3} \mathrm{O}_{4} / \mathrm{MnO}_{2} / \mathrm{SiO}_{2}-\mathrm{KCC}-1\left(0.4 \mathrm{mg} \mathrm{ml}^{-1}\right)$ with different concentrations $\mathrm{Cu}(\mathrm{II})$ ion in the Tris- $\mathrm{HCl}$ solution $(10 \mathrm{mM}, \mathrm{pH}=7.20)$. (b) The Stern-Volmer plot between various concentrations of $\mathrm{Cu}(\mathrm{II})$ ion and $F_{0} / F$ values. Error bars represents the standard deviations of the results from three independent experiments.

concentration in the range of $0-5 \times 10^{-4} \mathrm{M}$ with the correlation coefficient $R^{2}=0.9882$ is shown in Fig. $8 \mathrm{~b}$. The detection limit was calculated by the $3 \sigma / k$ method (where $\sigma$ is the standard deviation of the blank measurement and $k$ is the slope) to be about $12.3 \times 10^{-8} \mathrm{M}$, which was comparable to that of other methods (Table 1). Moreover, the linear relationship data fitting with Stern-Volmer plot expressed the 1 : 1 complex formation.

3.3.3. Selectivity and coexisting ion effect on the hybrid sensor I. The selectivity of the hybrid sensor I for $\mathrm{Cu}$ (II) ion was examined by testing the response of the system to various other metal ions including $\mathrm{K}(\mathrm{I}), \mathrm{Ag}(\mathrm{I}), \mathrm{Ca}(\mathrm{II}), \mathrm{Ni}(\mathrm{II}), \mathrm{Hg}(\mathrm{II}), \mathrm{Pb}(\mathrm{II}), \mathrm{Zn}$ (II), $\mathrm{Co}(\mathrm{II}), \mathrm{Ba}(\mathrm{II}), \mathrm{Fe}(\mathrm{II})$, and $\mathrm{Cd}$ (II) via both UV-visible absorption and fluorescence emission spectra under identical condition as used with $\mathrm{Cu}(\mathrm{II})$ (Fig. 9a). Compared to the remarkable enhancement of absorption intensity in the fluorescent spectra of the hybrid sensor I induced by $\mathrm{Cu}$ (II), no significant change was caused by other metal ions. ${ }^{41}$ Consistent with the absorption enhancement, the hybrid sensor I system obviously changed from colourless to pink after the addition of $\mathrm{Cu}$ (II). This result clearly indicates that $\mathrm{Cu}(\mathrm{II})$ is one of the well-known 
Table 1 Comparison between the proposed method and other methods for the detection of $\mathrm{Cu}(I)$

\begin{tabular}{|c|c|c|c|c|}
\hline Materials & Detection methods & Working range (M) & LOD & Ref. no. \\
\hline SBA-15 & Colorimetric sensor & $0.01-1.0 \times 10^{-6}$ & $0.015 \times 10^{-6}$ & 43 \\
\hline SBA-15 & Electrochemical sensor & $8.0-100.0 \times 10^{-7}$ & $2.0 \times 10^{-7}$ & 44 \\
\hline SBA-15 & $\begin{array}{l}\text { Fluorescence } \\
\text { chemosensor }\end{array}$ & $0-50 \times 10^{-6}$ & $0.1 \times 10^{-6}$ & 45 \\
\hline HOM-11 & Colorimetric sensor & $1.57 \times 10^{-8}$ to $7.86 \times 10^{-6}$ & $3.1 \times 10^{-8}$ & 46 \\
\hline Silica nanoparticles & Colorimetric sensor & $0-6.0 \times 10^{-4}$ & $2.13 \times 10^{-6}$ & 47 \\
\hline SBA-15 & Optical sensor & - & $3.2 \times 10^{-6}$ & 48 \\
\hline KCC-1 & $\begin{array}{l}\text { Fluorescence } \\
\text { chemosensor }\end{array}$ & $0-5 \times 10^{-4}$ & $12.3 \times 10^{-8}$ & Present wok \\
\hline
\end{tabular}
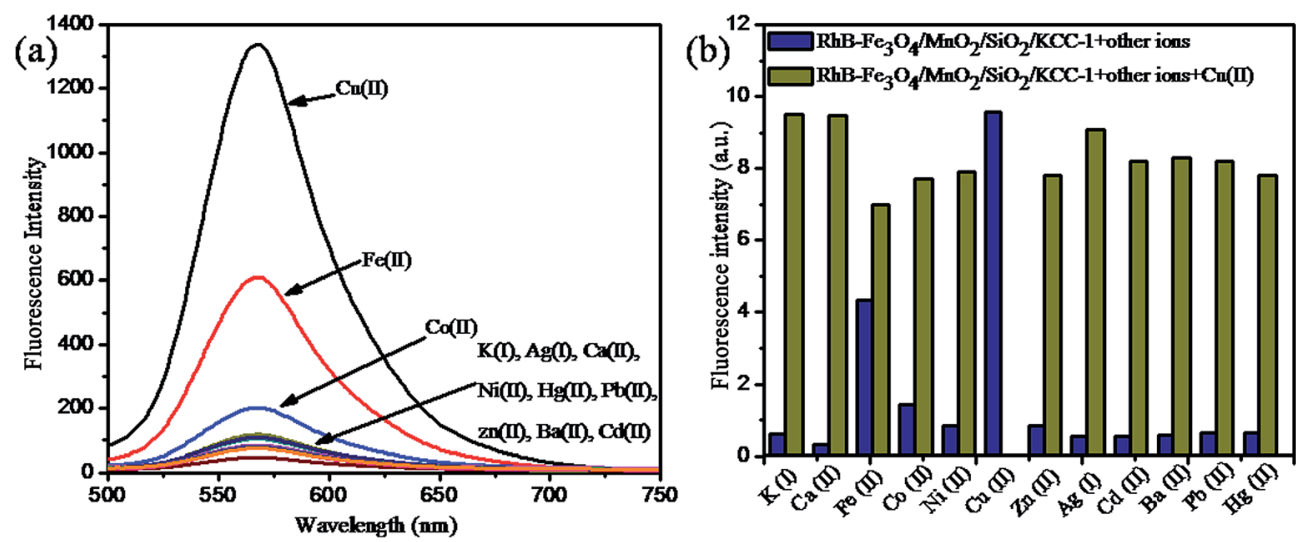

Fig. 9 Fluorescence spectra of (a) $\mathrm{RhB}-\mathrm{Fe}_{3} \mathrm{O}_{4} / \mathrm{MnO}_{2} / \mathrm{SiO}_{2} / \mathrm{KCC}-1\left(0.4 \mathrm{mg} \mathrm{ml}^{-1}\right)$ in the Tris $-\mathrm{HCl}$ solution (10 mM, $\left.\mathrm{pH}=7.2\right)$ with different metal ions $\left(5.0 \times 10^{-4} \mathrm{M}\right)$, (b) the fluorescence responses of $\mathrm{RhB}-\mathrm{Fe}_{3} \mathrm{O}_{4} / \mathrm{MnO}_{2} / \mathrm{SiO}_{2} / \mathrm{KCC}-1\left(0.4 \mathrm{mg} \mathrm{ml}^{-1}\right)$ various cations in water (pH $\left.=7.2\right)$. The blue bars represent the emission spectra of various interfering ions $\left(5.0 \times 10^{-4} \mathrm{M}\right)$. The green bars represent the change in emission spectra of upon the addition of $\mathrm{Cu}(\mathrm{II})\left(4.0 \times 10^{-4} \mathrm{M}\right)$. The intensities were recorded at $\lambda_{\mathrm{ex}}=520 \mathrm{~nm}$ and $\lambda_{\mathrm{em}}=569 \mathrm{~nm}$.

paramagnetic metal ions. This hybrid sensor I displayed the chelation-enhanced fluorescence (CEFE) that was attributed to the spiro-opening of the bis rhodamine Schiff-base derivative after the complexation with $\mathrm{Cu}(\mathrm{II})$ ion, which was induced by the intermolecular electron transfer from the rhodamine group to cationic metal ion. ${ }^{42}$ To further explore the selectivity of the hybrid sensor I towards $\mathrm{Cu}(\mathrm{II})$, a competition experiment was conducted via the additional mixing of $\mathrm{Cu}(\mathrm{II})$ with a solution containing other metal ions (Fig. 9b). The bar graph of the fluorescence emission intensity revealed that $\mathrm{Cu}$ (II) fluorescence enhancement of the hybrid sensor I almost remained unaffected in the presence of other metal ions at higher concentrations. Hence, the abovementioned results of the optical experiments indicated that the hybrid sensor I had a high sensitivity and selectivity towards $\mathrm{Cu}$ (II) with no interference by other metal ions even at higher concentrations. Thus, our result reveals that the hybrid sensor I is a selective chemosensor for the detection of $\mathrm{Cu}(\mathrm{II})$ ion.

3.3.4. Influence of $\mathbf{p H}$ values. Usually, the $\mathrm{pH}$ values of the solution have a remarkable influence on the fluorescence probe for the detection of target analytes. Thus, the $\mathrm{Cu}(\mathrm{II})$ sensing ability of the hybrid sensor I at different $\mathrm{pH}$ values was investigated. The $\mathrm{pH}$ value was adjusted in the range from 2 to 10 , and the fluorescence emission intensities were measured, as shown in Fig. 10. We have observed that the fluorescence

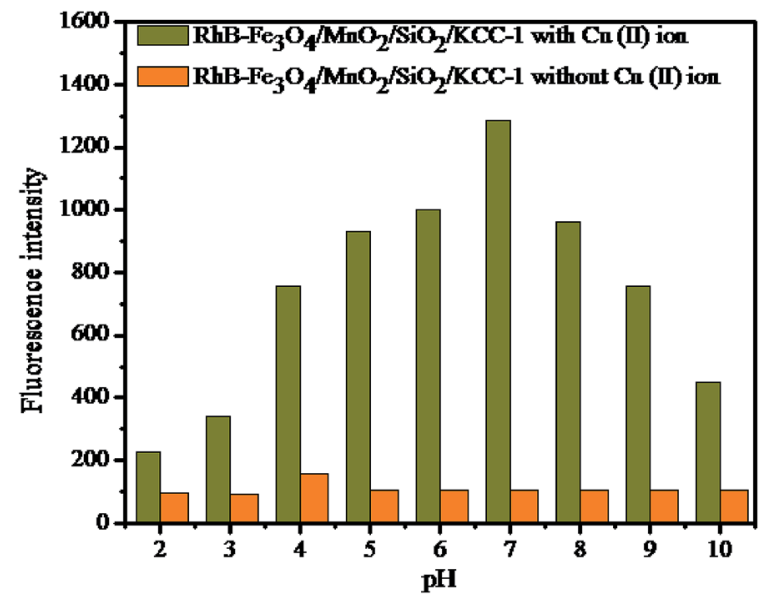

Fig. 10 The fluorescence response of $\mathrm{RhB}-\mathrm{Fe}_{3} \mathrm{O}_{4} / \mathrm{MnO}_{2} / \mathrm{SiO}_{2} / \mathrm{KCC}-1$ in $\mathrm{CH}_{3} \mathrm{CN} / \mathrm{H}_{2} \mathrm{O}$ as a function of $\mathrm{pH}$.

intensity of the hybrid sensor I increases with the increasing $\mathrm{pH}$ value because $\mathrm{Cu}(\mathrm{II})$ has a high affinity to chelate with fluorophoric carbonyl $(\mathrm{O})$, imino $(\mathrm{N})$, and phenol $(\mathrm{O})$ atoms to form a ring-opened amide form to enhance the fluorescence intensity. When the $\mathrm{pH}$ values changed from 5 to 8 , the dissociation reaction of amino groups played a key role on the surface of the 
hybrid sensor I. Thus, the strong fluorescence response was observed when $\mathrm{pH}<5$ because the deprotonated imine, carbonyl, and phenol groups were protonated, and the resulting ligands were separated from the surface of the hybrid sensor I. The results indicate a weak emission response in an acidic medium that can be attributed to the poor binding response of $\mathrm{Cu}(\mathrm{II})$ because the sensing probes tend to protonate. At a higher $\mathrm{pH}$ in the range from 5 to 8 , the amino groups tend to deprotonate; this create a feasible environment for the detection of $\mathrm{Cu}(\mathrm{II})$ ion. Taking this type of $\mathrm{pH}$ influence behaviour into account, the practical sensing in $\mathrm{CH}_{3} \mathrm{CN} /$ water solution $(1: 1$, $\mathrm{v} / \mathrm{v}$ ) with a buffer solution is highly accurate and reliable.

3.3.5. Recycling of the hybrid sensor I. The recycling performance of the hybrid sensor I after the addition of $\mathrm{Cu}$ (II) $\left(5.0 \times 10^{-4} \mathrm{M}\right)$ ions was investigated. As shown in Fig. $11 \mathrm{~A}-\mathrm{D}$, the absence of $\mathrm{Cu}$ (II) ion in the hybrid sensor I caused no change in the fluorescence enhancement (bar graph A). After the addition of $\mathrm{Cu}$ (II) ion to the abovementioned sensing system, the fluorescence intensity dramatically increased (bar graph B) and fully recovered upon the addition of EDTA $\left(5.0 \times 10^{-4} \mathrm{M}\right)$ (bar graph C). When $\mathrm{Cu}(\mathrm{II})$ was added in excess, the fluorescence emission intensity reached the saturation level again (bar graph D). Further subsequent addition of $\mathrm{Cu}(\mathrm{II})$ ion showed no

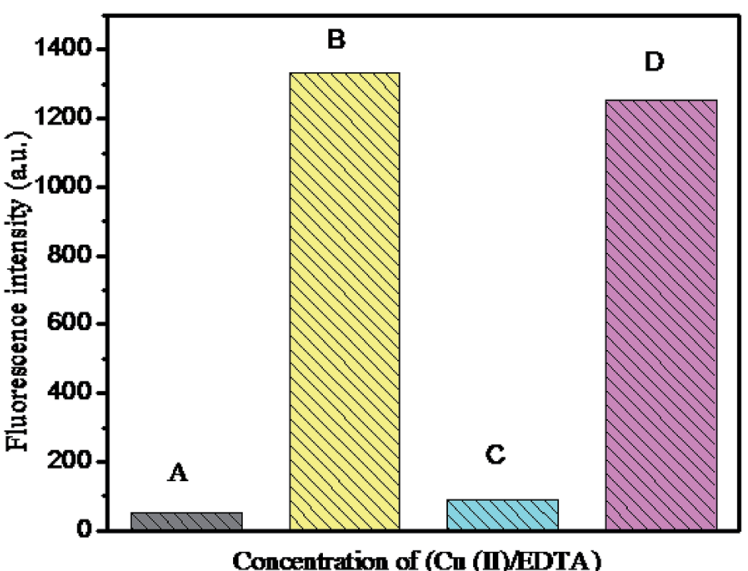

Fig. 11 Fluorescence spectra of $\mathrm{RhB}-\mathrm{Fe}_{3} \mathrm{O}_{4} / \mathrm{MnO}_{2} / \mathrm{SiO} / \mathrm{KCC}-1$ (0.4 $\left.\mathrm{mg} \mathrm{ml}^{-1}\right)$ in the Tris- $\mathrm{HCl}$ solution $(10 \mathrm{mM}, \mathrm{pH}=7.2)$. In bar graph (A) $\mathrm{RhB}-\mathrm{Fe}_{3} \mathrm{O}_{4} / \mathrm{MnO}_{2} / \mathrm{SiO}_{2} / \mathrm{KCC}-1$, (B) $\mathrm{RhB}-\mathrm{Fe}_{3} \mathrm{O}_{4} / \mathrm{MnO}_{2} / \mathrm{SiO} 2 / \mathrm{KCC}-1$ $+\mathrm{Cu}\left(\right.$ (I) $\left(5.0 \times 10^{-4}\right),(\mathrm{C}) \mathrm{RhB}-\mathrm{Fe}_{3} \mathrm{O}_{4} / \mathrm{MnO}_{2} / \mathrm{SiO}_{2} / \mathrm{KCC}-1+\mathrm{Cu}(I)(5.0 \times$ $\left.10^{-4}\right)+\operatorname{EDTA}\left(5.0 \times 10^{-4} \mathrm{M}\right)$, and (D) $\mathrm{RhB}-\mathrm{Fe}_{3} \mathrm{O}_{4} / \mathrm{MnO}_{2} / \mathrm{SiO}_{2} / \mathrm{KCC}-1+$ $\mathrm{Cu}(\mathrm{II})\left(10 \times 10^{-4}\right)+$ EDTA.

Table 2 Determination of $\mathrm{Cu}(॥)$ ion in the environmental water samples

\begin{tabular}{lllcc}
\hline Samples & $\begin{array}{l}\text { Spiked } \\
{[\mathrm{Cu}(\mathrm{II})] /(\mu \mathrm{M})}\end{array}$ & $\begin{array}{l}\text { Found } \\
\mathrm{Cu}(\mathrm{II}) /(\mu \mathrm{M})\end{array}$ & $\begin{array}{l}\text { Recovery } \\
(\%)\end{array}$ & $\begin{array}{l}\text { RSD } \\
(\%)\end{array}$ \\
\hline Tap water & 2 & 1.99 & 99.5 & 1.24 \\
River water & 4 & 3.98 & 99.5 & 2.23 \\
Pond water & 6 & 6.05 & 101 & 1.03 \\
Industrial & 8 & 3.99 & 99.8 & 1.99 \\
waste water & & & &
\end{tabular}

obvious change in the fluorescence emission. These results demonstrated that the hybrid sensor I had a superiority of recycling performance for the detection of $\mathrm{Cu}$ (II) ion.

3.3.6. Analysis of the environmental water sample. To identify the performance of the abovementioned chemosensor, we attempted to detect the concentration of $\mathrm{Cu}$ (II) in the environmental water samples. The water samples (including tap water, pond water, and industrial waste water) obtained near the SRM University campus were filtered to remove the solid impurity, and pH was adjusted to 7.2 using the Tris-HCl buffer for effective analysis in a neutral medium. The desired amount of $\mathrm{Cu}(\mathrm{II})$ ion was spiked $(2,4,6$, and $8 \mu \mathrm{M})$ into water samples followed by the addition of the hybrid sensor I to each sample. The obtained results are summarized in Table 2. They prove that this sensing system is able to determine $\mathrm{Cu}(\mathrm{II})$ in environmental water samples.

\section{Conclusion}

We have successfully prepared a hybrid magnetic core-shell fibrous silica nanocomposite and covalently functionalized it with a rhodamine-based derivative. The rhodamine-based derivative was modified with nitrogen and oxygen atoms, which strongly bonded to $\mathrm{Cu}$ (II) ion, playing a critical role in the selective detection of $\mathrm{Cu}$ (II) ion. This hybrid sensor exhibited significantly improved sensing ability towards $\mathrm{Cu}$ (II) ion with high sensitivity and selective fluorescence responses in an aqueous solution. The detection limit was found to be $12.3 \times$ $10^{-8} \mathrm{M}$, which was superior to that of the previously reported $\mathrm{Cu}$ (II) detection methods. In addition, this hybrid sensing system recovered $95 \%$ original fluorescence sensing signal for the detection of $\mathrm{Cu}$ (II) ion. The abovementioned results demonstrated the successful use of this nanocomposite for the detection of $\mathrm{Cu}(\mathrm{II})$ in the environmental real samples. Thus, this simple and reliable hybrid sensor can be used for $\mathrm{Cu}$ (II) ion detection in aqueous solutions.

\section{Conflicts of interest}

There are no conflicts to declare.

\section{Acknowledgements}

This work was financially supported by the SRM University, Department of Chemistry, Tamil Nadu, India.

\section{References}

1 E. Gaggelli, H. Kozlowski, D. Valensin and G. Valensin, Chem. Rev., 2006, 106, 1995.

2 K. J. Barnham, C. L. Masters and A. I. Bush, Nat. Rev. Drug Discovery, 2004, 3, 205.

3 M. Wang, K. H. Leung, S. Lin, D. S. Chan, D. W. J. Kwong, C. H. Leung and D. L. Ma, Sci. Rep., 2014, 4, 6794.

4 S. V. Wegner, H. Arslan, M. Sunbul, J. Yin and C. He, J. Am. Chem. Soc., 2010, 132, 2567. 
5 W. Cho, H. J. Lee, S. Choi, Y. Kim and M. Oh, Sci. Rep., 2014, 4, 1.

6 Y. Zhao, X. Zhang, Z. Han, L. Qiao, C. Li, L. Jian, G. Shen and R. Yu, Anal. Chem., 2009, 81, 7022.

7 M. A. Shenashen, S. A. EI-Safty and E. A. Elshehy, J. Hazard. Mater., 2013, 260, 833.

8 Z. Sun, D. Guo, L. Z. Haizhen Li, B. Yang and S. Yan, J. Mater. Chem. B, 2015, 3, 3201.

9 J. Yeh, W. Chen, S. Liu and S. Wu, New J. Chem., 2014, 38, 4434.

10 S. Li, X. Chen, W. Ma, Z. Ding, C. Zhang, Z. Chen, X. He, Y. Shang and Y. Zou, Sci. Rep., 2016, 6, 36654.

11 D. Bagal-Kestwal, M. S. Karve, B. Kakade and V. K. Pillai, Biosens. Bioelectron., 2008, 24, 657.

12 T. Radu and D. Diamond, J. Hazard. Mater., 2009, 171, 1168. 13 A. R. Thiruppathi, B. Sidhueddy, W. Keeler and A. Chen, Electrochem. Commun., 2017, 76, 42.

14 Y. Fang, Y. Zhou, Q. Rui and C. Yao, Organometallics, 2015, 34, 2962.

15 A. K. Mahapata, S. K. Manna, D. Mandal and C. D. Mukhopadhyay, Inorg. Chem., 2013, 52, 10825.

16 X. Meng, Y. Xu, J. Liu, L. Sun and L. Shi, Anal. Methods, 2015, 8, 1044.

17 F. Huo, C. Yin, Y. Yang, J. Su, J. Chao and D. Liu, Anal. Chem., 2012, 84, 2219.

18 L. Huang, X. Wang, G. Xie, P. Xi, Z. Li, M. Xu, Y. Wu, D. Bai and Z. Zeng, Dalton Trans., 2010, 39, 7894.

19 M. Zhao, X. Yang, S. He and L. Wang, Sens. Actuators, B, 2009, 135, 625.

20 S. M. Sadeghzadeh, RSC Adv., 2016, 6, 75973.

21 Y. Wang, B. Li, L. Zhang, L. Liu, Q. Zuo and P. Li, New J. Chem., 2010, 34, 1946.

22 Y. Wang, B. Li, L. Zhang, P. Li, L. Wang and J. Zhang, Langmuir, 2012, 28, 1657.

23 L. Zhao, D. Sui and Y. Wang, RSC Adv., 2015, 21, 16611.

24 P. Pal, S. K. Rastogi, C. M. Gibson, D. E. Aston, A. L. Branen and M. E. Bitterwolf, ACS Appl. Mater. Interfaces, 2011, 3, 279.

25 H. Zhang, P. Zhang, K. Ye, Y. Sun, S. Jiang, Y. Wang and W. Pang, J. Lumin., 2006, 117, 68.

26 Z. Sun, H. Li, D. Guo, J. Sun, G. Cui, Y. Liu, Y. Tian and S. Yan, J. Mater. Chem. C, 2015, 3, 4713.

27 N. Bayal, B. Singh, R. Singh and V. Polshettiwar, Sci. Rep., 2016, 6, 1 .
28 S. Wang, K. Wang, C. Dai, H. Shi and J. Li, Chem. Eng. J., 2015, 62, 897.

29 L. Dong, C. Wu, X. Zeng, L. Mu, S. Xue, Z. Tao and J. Zhang, Sens. Actuators, B, 2010, 145, 433.

30 Z. Zhao, J. Liu, F. Cui, H. Feng and L. Zhang, J. Mater. Chem., 2012, 22, 9052.

31 J. Sun, J. Zhuang, S. Guan and W. Yang, J. Nanopart. Res., 2008, 10, 653.

32 T. Gulin-Sarfraz, J. Zhang, D. Desai, J. Teuho, J. Sarfraz, H. Jiang, C. H. Zhang, C. Sahlgren, M. Linden, H. Coeen Gu and J. M. Rosenholm, Biomater. Sci., 2014, 2, 1750.

33 S. M. Sadeghzadeh, RSC Adv., 2016, 6, 75973.

34 L. Zhang, J. Lian, L. Wu, Z. Duan, J. Jian and L. Zhao, Langmuir, 2014, 30, 7006.

35 Y. Wang, X. Peng, J. Shi, X. Tang, J. Jiang and W. Liu, Nanoscale Res. Lett., 2012, 7, 1.

36 Y. Wang, X. Peng, J. Shi, X. Tang, J. Jiang and W. Liu, Nanoscale Res. Lett., 2010, 7, 86.

37 Z. Sun, D. Guo, L. Z. Haizhen Li, B. Yang and S. Yan, J. Mater. Chem. B, 2015, 3, 3201.

38 X. W. Cheng, Y. Zhou, Y. Fang, Q. Rui and C. Yao, RSC Adv., 2015, 5, 19465.

39 P. Zhou, Q. Meng, G. He, H. Wu, C. Duan and X. Quan, J. Environ. Monit., 2009, 11, 648.

40 X. Zeng, Y. Xu, X. Chen, W. Ma and Y. Zhou, Appl. Surf. Sci., 2017, 423, 1103.

41 X. Qiu, S. Han, Y. Hu, M. Gao and H. Wang, J. Mater. Chem. A, 2014, 2, 1493.

42 X. Tian, Z. Dong, R. Wang and J. Ma, Sens. Actuators, B, 2013, 186, 446.

43 Z. Wang, M. Wang, G. Wu, D. Wu and A. Wu, Dalton Trans., 2014, 43, 8461.

44 I. Cesarino, G. Marino, J. D. Rosario Matos and E. T. Gomes Cavalheiro, Talanta, 2008, 75, 15.

45 L. Gao, J. Q. Wang, L. Huang, X. X. Fan, J. H. Zhu, Y. Wang and Z. G. Zou, Inorg. Chem., 2007, 46, 10287.

46 S. A. El-Safty, A. A. Ismail and A. Shahat, Talanta, 2011, 83, 1341.

47 L. Li, H. Sun, C. Fang, J. Xu, J. Y. Jin and C. Yan, J. Mater. Chem., 2007, 17, 4492.

48 D. B. Kim, J. M. Hong and S. Chang, Sens. Actuators, B, 2017, 252, 537. 